\title{
Sabine MacCormack y los Andes
}

\author{
Catherine MacCormack
}

\section{RESUMEN}

Sabine MacCormack fue una gran viajera y lo fue en muchos sentidos, no sólo en el espacio de varios mundos y numerosas culturas. Su vida vino a reflejar así como una síntesis de realidades, como un conjunto que supera la mera suma de sus partes. Lejos de limitarse a un pasado hecho de cosas perdidas y de conflictos, ella dibujaba en el pasado nuevos territorios de sanación personal y de entendimiento cultural interdisciplinario. La experiencia extensa y directa de Sabine del mundo andino ayudó a conciliar su pensamiento, su sentido comunitario y su pertenencia y presencia espiritual en el mundo físico.

Palabras clave: Sabine MacCormack, Andes coloniales, remembranza, retrato, comprensión intercultural

\section{Abstract}

Sabine MacCormack was a voyager in many worlds and many cultures throughout a life that came to reflect a synthesis of realities into a whole greater than the sum of the parts. Out of pasts that signified loss and war she charted new territories of personal healing and interdisciplinary cultural understanding. 
Sabine's extensive and direct experience in Andean landscapes came to guide her thinking, reflecting community, belonging and her spiritual presence in the physical world.

KEYwords: Sabine MacCormack, colonial Andes, Resemblance, portrait, intercultural understanding

Sabine fue una gran viajera y lo fue en muchos sentidos, no solo en el espacio de varios mundos y numerosas culturas. Su vida vino a reflejar así como una síntesis de realidades, como un conjunto que supera la mera suma de sus partes. Lejos de limitarse a un pasado hecho de cosas perdidas y de conflictos, dibujaba en el pasado nuevos territorios de sanación personal y de entendimiento cultural interdisciplinario. Ella era al mismo tiempo viajera, artista, humanista, investigadora de archivos y, por supuesto, historiadora de la cultura. Mi padre ha dicho muchas veces que era bondadosa y lo reflejaba en cada cosa que hacía, incluyendo, entre otras, los arreglos y la decoración de la casa, el empacar la frágil porcelana con tanta perfección que ni había la más mínima rotura luego de atravesar continentes enteros, también en el cuidado del jardín y lo mismo al hablar distintos idiomas o al debatir ideas. Con el tiempo, la amistad se volvió algo esencial en cada día de su vida, como al compartir los alimentos que ella preparaba en base de piqueos servidos en platos de distintas vajillas, todo con vino tinto servido en tazas de plata o loza.

La energía y dedicación de Sabine a su trabajo eran invencibles. Apenas luego de su sorpresiva y lastimosa muerte, yo me planté en la puerta de su casa en South Bend con David Dressing y David Sullivan, bibliotecarios de la Universidad de Notre Dame, maravillados por la cantidad de cuadernos que había llenado densamente con notas sobre manuscritos y libros raros y detallados dibujos de imágenes y altares, junto a estantes y estantes de fotocopias anilladas y cuidadosamente ordenadas y engrapadas por carpetas, producto de décadas de concentrada labor académica. Cuando yo era 
joven, recuerdo usar una máquina Xerox por primera vez y tratar de repetir la velocidad de Sabine y su destreza en colocar los originales, página tras página, en la posición correcta del cristal mientras seguía sus precisas instrucciones para no dañar el volumen.

En todos sus trabajos, siempre abogaba por la promoción de mentes inquisitivas y creadoras, invitándolas a compartir su interés por el conocimiento desde todos los caminos de la vida y apoyando a las instituciones y sistemas que los ayudaban. En el curso de muchos años fue añadiendo a su propia biblioteca, conforme iba escribiendo algún libro o artículo, distintos volúmenes, manuscritos y separatas de todas partes del mundo. Su biblioteca era su casa. Viajar le proporcionaba un escape de la rutina académica y su biblioteca le otorgaba un santuario doméstico como contraparte de las diversas vicisitudes políticas y sociales de la vida académica.

Sabine adoraba viajar. Los viajes eran una de sus razones de vivir y eso se reflejaba en su manera intensa de hacer las cosas, con una extraordinaria resistencia que la llevaba más allá de los límites de lo que la mayoría de la gente hace o considera posible hacer. Vivía mirando adelante, aunque algunos fantasmas dolorosos del pasado estaban a veces más presentes de lo que ella aceptaba reconocer, a los que se refería como sus «demonios». Permanecer demasiado tiempo en un solo lugar con rutinas y personas establecidas podía acercarla, paradójicamente, a un sentimiento de pérdida profunda o a una sensación de inadecuación. Por muchos años, cada área de su vida y ella misma, de cara a sus ojos, resultaban siempre algo insuficientes.

Sabine pasó horas pintando paisajes tan variados como las montañas andinas y las abarrotadas calles de Benarés. Podía permanecer sentada, inmóvil, mientras con una mano metía la brocha dentro de un vasito de plata, mezclando pinturas, aplicando color al papel blanco con firmes pinceladas y tomando con la otra mano ocasionales sorbos de vino de una copa plateada, y las más de las veces declaraba que el resultado no ofrecía una imagen justa de lo que había visto. La 
alegría de ver con sus propios ojos que una imagen reflejaba lo que había percibido en el paisaje era una alegría también para mí y encajaba en una comunión con la profundidad del espacio. La experiencia extensa y directa de Sabine de muchos paisajes tanto como artista y como exploradora, combinada con su conversión al catolicismo en la última década de su vida, le ayudaron a sentir un balance interior y renovaron su conexión con la vida.

Lo que Sabine vio y articuló -porque ella imaginó lo que los incas y los cristianos vieron reflejado en sus lugares e imágenes sagrados tanto como en sus textos- era la energía y el poder transformador que la cultura andina dio al cristianismo. Pero era también las amistades que ella hizo en el Perú lo que ayudó a afianzar en ella misma ese inmenso amor que tenía por los Andes. Un día, justo antes del trabajo, tenía urgencia irresistible de llamarla y luego de una breve charla encantadora en la que me hablaba de sus amigos en Lima yo me quedaba maravillada del poder de la alegría y de la energía de su voz.

Cuando acompañé a Sabine en su viaje al Perú en el verano de 1985, encontramos una luz en medio de un conflicto personal que muchos años después me recordó su habilidad para superar oposiciones internas y externas sin contradicción. Durante aquel verano, seguía la acostumbrada rutina a través de una combinación de estrategias que había mantenido durante todas sus travesías, consiguiendo acceso a los archivos y dedicando días enteros al trabajo que la encaminaba a través de manuscritos que reflejaban su propia historia de conflicto y reconciliación con Dios y con lo espiritual. En el camino a Machu Picchu nuestro tren atropelló a una mujer andina que iba caminando por los rieles y la dejó con un rostro irreconocible. Horas más tarde, sentadas delante de la montaña de Machu Picchu, Sabine pintó una imagen sobrenatural que mostraba una forma oscura trascendiendo al mundo del espíritu.

Nada disuadía a Sabine de su búsqueda de un conocimiento directo de las cosas. Igual en las calles de Lima, donde una vez había 
ocurrido una balacera o en los alrededores de Pisaq. Estábamos trepando todo lo rápido que podíamos la ladera de una montaña y la cartuchera de pinturas que llevaba yo parecía llena de rocas. En el pueblecito que encontramos horas después, me comí un huevo y fue el mejor que yo haya probado en mi vida y dormimos con un frío extremo bajo un cobertor. Sabine soportaba bien el frío y el calor, los robos, el hambre y varios episodios severos de desarreglos estomacales a causa de ese viajar durante años. Aprendí de ella a tener tanto un sentido de esperanza imborrable y al mismo tiempo sentir un pozo de profunda desesperanza. Ella seguía adelante sin importar cuál de las dos cosas prevalecía.

En los últimos años, nos aleccionaba intensamente sobre el amor y la mortalidad y acudía diariamente a la iglesia de la comunidad en la catedral de San Mateo, en South Bend, más afín a ella que la catedral de Notre Dame con su cúpula dorada. Fundó y llevó adelante el programa de enseñanza de quechua en Notre Dame, con la misma visión de futuro con la que implementó o completó las bibliotecas en las muchas instituciones donde trabajaba y enseñaba. El programa trajo la comunidad y los Andes a la vida diaria de Sabine, en particular, en los casos de Inés y Gina quienes, con Bill y Mr. B., formaron sus familias en South Bend. Sentados con ellos y Sabine en la misma mesa de la cocina en la que me sentaba desde muy pequeña, sentía entonces un renovado equilibrio entre el pasado vital de Sabine y su propia paz interior.

Los años que Sabine pasó en los Andes la ayudaron a construir un puente entre el abismo que la llevó a conformar su fe en Dios y le dieron la perspectiva con que supo sentirse aceptada y aceptable y, más allá de la aceptación, a abrazar el amor. Sabine a veces se quejaba de la cantidad de esfuerzo que le suponía atender a los invitados, sobre todo porque ella llegaba a ser especialmente dedicada al ofrecerles su hospitalidad y ayudaba de verdad a aquellos que se la pasaban lejos de casa y que no encajaban bien en el molde académico general. Sus cenas célebres, en torno a una mesa 
con velas y precedidas por vasos de vino, aceitunas, salami curado y excelentes quesos con galletas de soda, fueron ocasiones maravillosas de amistad, buena comida y buena bebida y un buen tema de conversación que dejaron recuerdos entrañables del momento. Durante estas reuniones Sabine a menudo llevaba alguna prenda de lana tejida en los Andes, ya fuera una vincha, una chalina o un poncho. Los motivos y el estilo de las vestimentas andinas llegaron a ser parte de ella, no solo objetos externos que atesoraba con devoción, sino que, más aún, eran verdaderamente una parte de lo que vino a guiar su pensamiento, su sentido comunitario y su pertenencia y presencia espiritual en el mundo físico.

«Pachamama», diría ella, vertiendo el concho de vino de su copa de plata sobre la tierra. 